\title{
Effects of Matric and Osmotic Priming Treatments on Broccoli Seed Germination
}

\author{
Lewis W. Jett' ${ }^{1}$, Gregory E. Welbaum ${ }^{2}$, and Ronald D. Morse ${ }^{3}$ \\ Department of Horticulture, Virginia Polytechnic Institute and State University, Blacksburg, \\ VA 24061-0327
}

Additional index words. Brassica oleracea, stand establishment, temperature, root growth

\begin{abstract}
Priming, a controlled-hydration treatment followed by redrying, improves the germination and emergence of seeds from many species. We compared osmotic and matric priming to determine which was the most effective treatment for improving broccoli seed germination and to gain a greater understanding of how seed vigor is enhanced by priming. Broccoli (Brassica oleracea L. var. italica) seeds were osmotically primed in polyethylene glycol (PEG 8000) at -1.1 MPa or matrically primed in a ratio of $1.0 \mathrm{~g}$ seed:0.8 g synthetic calcium silicate (Micro-Cel E):1.8 ml water at $-1.2 \mathrm{MPa}$. In the laboratory, germination rates and root lengths were recorded from 5 to $42 \mathrm{C}$ and 10 to $35 \mathrm{C}$, respectively. Broccoli seeds germinated poorly at $>35 \mathrm{C}$. Root growth after germination was more sensitive to temperatures $>30 \mathrm{C}$ and $<15 \mathrm{C}$ than radicle emergence. Matric and osmotic priming increased germination rate in the laboratory, greenhouse, and field. However, matric priming had a greater effect on germination and root growth rates from 15 to $30 \mathrm{C}$. Neither priming treatment affected minimum or maximum germination or root growth temperatures. Both priming treatments decreased the mean thermal time for germination by $>35 \%$. The greater germination performance of matrically primed seeds was most likely the result of increased oxygen availability during priming, increased seed Ca content, or improved membrane integrity.
\end{abstract}

Uniform field establishment of broccoli seedlings concentrates harvests, increases harvest efficiency, and decreases costs (Heather and Sieczka, 1991). In the southeastern United States, high temperatures during August and September decrease stands of directseeded broccoli (Brassica oleracea L. var. italica), increasing the number of harvests and reducing fall crop yields (Elson et al., 1992; Jett et al., 1995; Sterrett et al., 1990). To compensate for poor emergence, broccoli is often direct-seeded at twice the rate required and thinned to a final stand of 11 plants $/ \mathrm{m}^{2}$ (O'Dell, 1990).

Broccoli seed germination decreases sharply above 30C, so improved high-temperature germination may also increase stands of summer plantings (Elson et al., 1992). Seed priming treatments improve germination performance in many species (Bradford, 1986; Khan 1992). Priming is a controlled-hydration process followed by redrying that allows pregerminative metabolic activities to proceed but prevents radicle emergence (Heydecker and Coolbear, 1977). When seeds are rehydrated after priming, germination rate is increased and, in some cases, the temperature range at which germination may occur is expanded (Welbaum and Bradford, 1991).

Osmotic and matric priming treatments enhance germination performance. For osmotic priming, seeds are incubated in salt solutions such as $\mathrm{KNO}_{3}, \mathrm{NaCl}$, or $\mathrm{K}_{3} \mathrm{PO}_{4}$ or high-molecularweight, nonpenetrating solutes like polyethylene glycol at a water potential $(\Psi)$ low enough to inhibit germination (Khan, 1992). Osmotic priming improves the germination performance of many Brassica spp. seeds such as Brussels sprouts (Brassica oleracea L.

Received for publication 12 Oct. 1995. Accepted for publication 16 Feb. 1996. We are grateful for the gift of broccoli seeds from Petoseed Co. Inc., Saticoy, Calif., and Sakata Seeds America, Inc., Morgan Hill, Calif., and Micro-Cel E from Manville Corp., Denver, Colo. Use of trade names does not imply endorsement of products named nor criticism of similar products not mentioned. The cost of publishing this paper was defrayed in part by the payment of page charges. Under postal regulations, this paper therefore must be hereby marked advertisement solely to indicate this fact.

${ }^{1}$ Currrent address: Louisiana State Univ. Sweet Potato Research Station, P.O. Box 120, Chase, LA 71324-0120.

${ }^{2}$ Assistant professor, welbaum@vt.edu.

${ }^{3}$ Associate professor. var. gemmifera), cabbage (Brassica oleracea L. var. capitata), and kale (Brassica oleracea L. var. acephala) (Khan et al., 1980-81; Rao et al., 1987). Osmotic priming increases the vigor of Brassica spp. seeds in cold, moist soils (Rao et al., 1987; Zheng et al., 1994).

Matric priming uses moistened solid carriers such as vermiculite or calcium silicate to hydrate seeds. In several vegetable species, matric-primed seeds germinate faster than osmotic-primed seeds, although the physiological basis for this difference is poorly understood (Khan, 1992). Matric priming is also widely used as a commercial seed treatment. However, the germination performance of osmotic- and matric-primed broccoli seeds has not been compared previously.

A comparison of several matric and osmotic priming treatments was conducted to identify the most effective treatment for improving broccoli seed germination in the laboratory, field, and greenhouse. To determine how priming increases seed vigor, the rate of oxygen uptake during priming, the mineral content, and the electrolyte leakage from imbibed nonprimed, osmotic-, and matricprimed seeds were measured.

\section{Materials and Methods}

Priming treatments. 'Brigadier' broccoli seeds (Petoseed Co., Saticoy, Calif.) were osmotically primed for 7 days in polyethylene glycol (Carbowax, PEG 8000; Fisher Scientific Co., Fair Lawn, N.J.) solutions of $-1.1 \mathrm{MPa}\left(306 \mathrm{~g} \cdot \mathrm{kg}^{-1}\right)$, prepared according to Michel (1983) and verified by osmometry (model 5500C; Wescor, Inc., Logan, Utah). Seeds were incubated in the dark on two thicknesses of filter paper (Whatman no. 1) saturated with PEG (about $7 \mathrm{ml} \cdot \mathrm{g}^{-1}$ seed) in $8.5-\mathrm{cm}^{2}$ petri dishes sealed with wax film (parafilm M; American National Can, Greenwich, Conn.) to prevent evaporation.

For matric priming, water and synthetic calcium silicate (Micro-Cel E, Manville Corp., Denver, Colo.) were mixed thoroughly in sealed $100-\mathrm{cm}^{3}$ jars for $24 \mathrm{~h}$ before the seeds were added. Each jar was rotated once daily to ensure uniform mixing of seeds and carrier for 7 days. After priming, seeds were removed either from solid carriers or osmotica, washed in tap water for $2 \mathrm{~min}$, briefly rinsed in $200 \mathrm{ml}$ of distilled water, blotted dry, and forced-air dried 
Table 1. Micro- and macronutrient contents of priming materials and broccoli seeds after priming.

\begin{tabular}{|c|c|c|c|c|c|c|c|c|}
\hline \multirow[b]{2}{*}{ Treatment } & \multicolumn{4}{|c|}{ Macronutrients } & \multicolumn{4}{|c|}{ Micronutrients (ppm) } \\
\hline & $\mathrm{P}$ & $\mathrm{K}$ & $\mathrm{Ca}$ & $\mathrm{Mg}$ & $\mathrm{Zn}$ & $\mathrm{Mn}$ & $\mathrm{Cu}$ & $\mathrm{Fe}$ \\
\hline Priming agent & \multicolumn{4}{|c|}{ (ppm) } & & & & \\
\hline Micro-Cel E & $15.5^{\mathrm{z}}$ & 33.0 & 1200.0 & 31.0 & 0.3 & 1.4 & 0.1 & 0.7 \\
\hline \multirow[t]{2}{*}{ PEG } & 31.0 & 1.5 & 12.0 & 1.0 & 0.2 & 0.5 & 0.1 & 0.9 \\
\hline & $* *$ & $* * *$ & $* * *$ & $* * *$ & NS & * & NS & NS \\
\hline Seeds & \multicolumn{4}{|c|}{$(\%)$} & & & & \\
\hline Matric-primed & $0.95 \mathrm{a}$ & $0.72 \mathrm{a}$ & $0.67 \mathrm{a}$ & 0.30 & 58 & 30 & 9 & $138 \mathrm{a}$ \\
\hline Osmotic-primed & $0.85 \mathrm{~b}$ & $0.71 \mathrm{a}$ & $0.48 \mathrm{~b}$ & 0.27 & 51 & 30 & 6 & $102 \mathrm{~b}$ \\
\hline \multirow[t]{2}{*}{ Nonprimed } & $0.94 \mathrm{a}$ & $0.88 \mathrm{~b}$ & $0.52 \mathrm{~b}$ & 0.29 & 52 & 32 & 7 & $160 \mathrm{a}$ \\
\hline & $*$ & $*$ & $*$ & NS & NS & NS & NS & * \\
\hline
\end{tabular}

${ }_{\mathrm{z}}$ Means are for two samples or two replications of 25 seeds each for priming agents and seeds, respectively, and are significantly different by LSD ${ }_{0.05}$ when separated by different letters within columns.

Ns, ${ }^{* * *},{ }^{* * *}$ Nonsignificant or significant at $P=0.05,0.01$, and 0.001 , respectively. Percentage data were arcsin-transformed before statistical analysis, and nontransformed values are shown.

at $37 \mathrm{C}$ for $20 \mathrm{~min}$. Seeds were final-dried over silica gel in a desiccator at $45 \%$ relative humidity $(\mathrm{RH})$ to a final moisture content of $5 \%$ to $6 \%$ (dry weight basis) determined by oven drying at $103 \mathrm{C}$ for $17 \mathrm{~h}$ (ISTA, 1985). Seeds were recoated with $1 \mathrm{~g}$ thiram (tetramethylthiuram disulfide) $/ 2500 \mathrm{~g}$ seed, sealed in plastic bottles, and stored at $4 \mathrm{C}$. The equilibrium $\Psi$ of seeds primed in Micro-Cel E was measured using a thermocouple psychrometer (model 85; J. R.D. Merrill, Logan, Utah) calibrated using $\mathrm{NaCl}$ solutions of known $\Psi$ verified by osmometry.

The plant-available, mineral nutrients in Micro-Cel E and PEG were determined by the double-acid extraction method using $4 \mathrm{~cm}^{3}$ of carrier in $20 \mathrm{ml}$ of $0.05 \mathrm{~N} \mathrm{HCl}$ in $0.025 \mathrm{~N} \mathrm{H}_{2} \mathrm{SO}_{4}$ (Donohue and Heckendorn, 1994). Seeds selected for mineral analysis were soaked in distilled water for $2 \mathrm{~h}$, rinsed in a stream of doubledistilled water, and dried in a desiccator at $45 \% \mathrm{RH}$. The mineral content of primed and nonprimed seeds was measured by A \& L Eastern Agricultural Labs, Inc., Richmond, Va., using a wet-ash extraction of $0.2 \mathrm{~g}$ of seed in $6 \mathrm{ml}$ of $2: 170 \%$ nitric- $60 \%$ perchloric acid. Tissue and carrier samples were filtered, diluted, and analyzed using an inductively coupled plasma spectrometer(Donohue and Heckendorn, 1994).

Germination and root growth. Germination temperatures of 5, $10,15,20,25,30,35,36,38,40$, and $42 \mathrm{C}$ were maintained on a one-dimensional, linear, thermo-gradient table. Three replicates of 20 seeds each of primed and nonprimed treatments were placed on two thicknesses of germination blotter paper (Anchor Paper Co., St. Paul, Minn.) inside 5.0-cm-diameter petri dishes (Seal Tight; Falcon, Lincoln Park, N.J.) moistened with $4 \mathrm{ml}$ of distilled water, randomized within each temperature, and incubated in the dark. A data logger (Polycorder; Omnidata Intl. Inc., Logan, Utah), connected to fine-wire copper-constantan thermocouples inside representative dishes, measured and recorded temperatures, which varied by $<1.0 \mathrm{C}$. Germination was scored as radicle emergence of at least $1 \mathrm{~mm}$ at 2 -h intervals for the first 3 days and $6 \mathrm{~h}$ thereafter until no further germination had occurred for $24 \mathrm{~h}$.

When radical protrusion reached at least $1 \mathrm{~mm}$, two replications of 10 seeds each were placed between two thicknesses of $12 \times 15$ $\mathrm{cm}$ germination blotter paper in a row $4 \mathrm{~cm}$ from the edge. Blotters were placed on $45^{\circ}$ slant boards in a dark incubator and covered with plastic bags to prevent evaporation (McCormac and Keefe, 1990). Root lengths were periodically measured with calipers (Digimatic, Mitutoyo Corp., Tokyo) at 10, 15, 20, 25, 30, and 35C.

Emergence experiments. Three replications of 10 primed and nonprimed seeds each were randomly sown $15 \mathrm{~mm}$ deep in $11-\mathrm{cm}-$ diameter plastic pots filled with potting soil (Pro-mix BX; Fisons
Horticultural Inc., Ont., Canada) in a randomized complete-block design in a greenhouse. Mean day/night temperatures were 25/ 20C, pots were hand-watered daily, and supplemental lighting (1000 W, 60 Hz, Sylvania Corp., Fall River, Mass.) provided a 14$\mathrm{h}$ photoperiod. Emergence was recorded when cotyledons were oriented horizontally above the soil. Plants were harvested 16, 30, and 44 days after seeding (DAS). Roots and shoots were separated and weighed fresh and after drying at $70 \mathrm{C}$ for $24 \mathrm{~h}$.

Three replications of 100 primed and 100 nonprimed 'Brigadier' seeds were hand-seeded $15 \mathrm{~mm}$ deep in twin rows $15 \mathrm{~m}$ long and $30 \mathrm{~cm}$ apart on 9 Sept. 1992 and 17 Aug. 1993 in a Hayter loam (fine-loamy, mixed mesic, Utic Hapludalf), pH of 6.2, near Blacksburg, Va. After sowing, $1.7 \mathrm{~cm}$ of water was applied using sprinkler irrigation to induce soil crusting. Emergence was recorded three times daily, when cotyledons were horizontal to the soil surface, until no further emergence was observed for $48 \mathrm{~h}$. Soil temperatures were recorded at seeding depth using copper-constantan thermocouples connected to a data logger.

Germination data analysis. Seed germination responses over time were linearized by transforming cumulative percent germination to probits and plotting the values on a logarithmic time scale (Scott and Jones, 1985). Mean time to germination (MTG) and mean time to emergence (MTE) were determined graphically from the probit value of $0 \%$ or $50 \%$ germination or emergence for each replication in treatments with at least $30 \%$ germination. The mean minimum or base temperature $\left(\mathrm{T}_{\mathrm{b}}\right)$ and the mean maximum temperature $\left(\mathrm{T}_{\mathrm{m}}\right)$ for root growth were determined by extrapolating plots of mean germination rate $\left(\mathrm{GR}=1 \cdot \mathrm{t}^{-1}=\right.$ inverse $\left.\mathrm{MTG}\right)$ or root growth rate versus temperature (T) to the intercept on the abscissa (Gummerson, 1986). Since the plot of GR versus T, was not linear at high temperature, the maximum $\mathrm{T}$ allowing $50 \%$ germination was used to estimate $T_{m}$. Mean thermal time to germination $\left(\theta_{\mathrm{T}},{ }^{\circ} \mathrm{h}\right)$ was determined by the following equation:

$\theta_{\mathrm{T}}=\left(\mathrm{T}-\mathrm{T}_{\mathrm{b}}\right) \mathrm{t}$

where $\mathrm{T}$ is the germination temperature, $\mathrm{T}_{\mathrm{b}}$ is the minimum mean temperature for germination, and $t$ is the MTG. Rearranging in terms of GR, yields the following:

$\mathrm{GR}=1 \cdot \mathrm{t}^{-1}=\left(\mathrm{T}-\mathrm{T}_{\mathrm{b}}\right) \theta_{\mathrm{T}}^{-1}$

indicating that the mean thermal time is the inverse slope of the plot of GR versus T. Thus, $\theta_{\mathrm{T}}$ is a rate constant that relates GR to the extent that $\mathrm{T}$ exceeds $\mathrm{T}_{\mathrm{b}}$. Germination percentages, rates, MTG, 
MTE, and base temperatures were compared by analysis of variance (ANOVA) (CoStat; CoHort Software, Minneapolis, Minn.) on arcsin-transformed percentage data and log-transformed time values. Untransformed values are shown in tables and figures.

Oxygen uptake measurement. A Clark-type, $\mathrm{O}_{2}$ electrode (model LD2; Hansatech Ltd. Norfolk, U.K.) measured $\mathrm{O}_{2}$ uptake of three
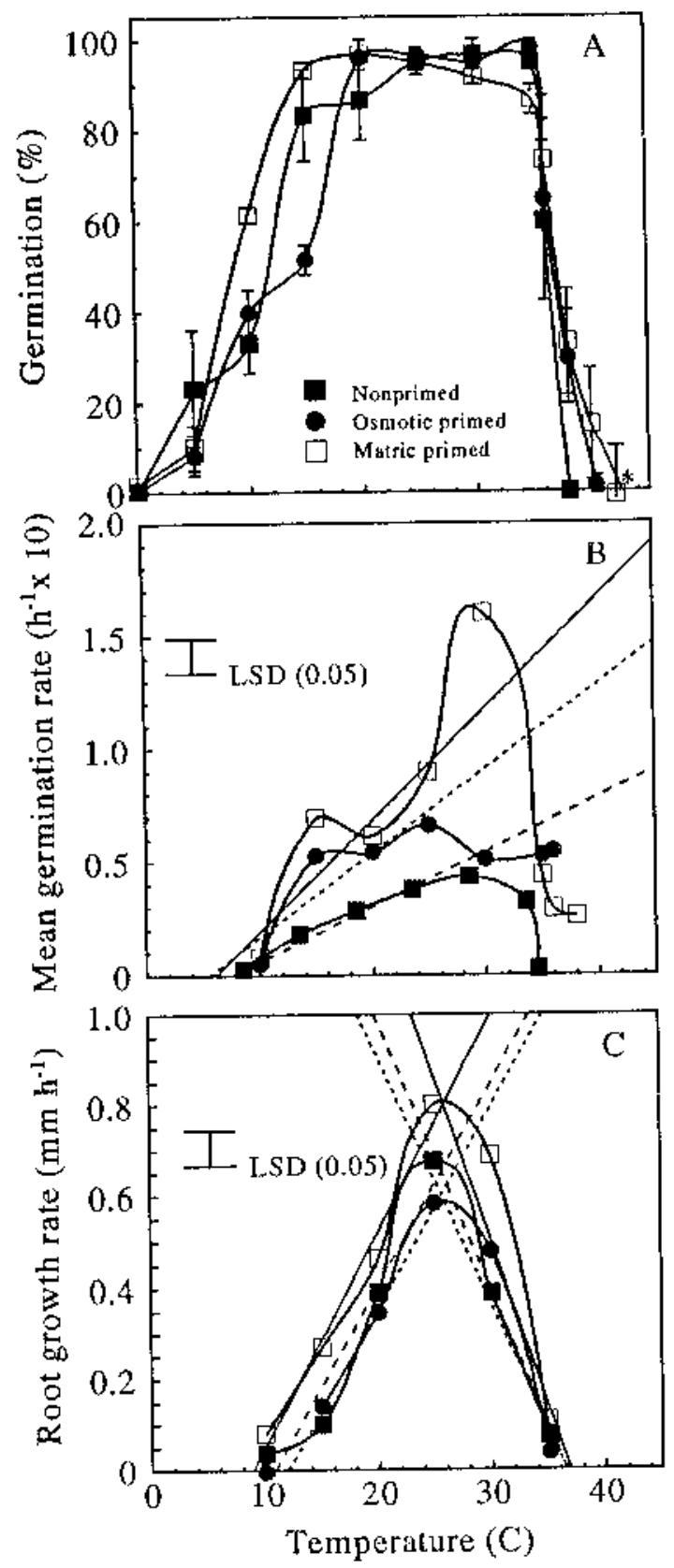

Fig. 1. Germination percent (A), germination rate $(\mathbf{B})$, and root length $(\mathbf{C})$ of matricprimed, osmotic-primed, and nonprimed broccoli seeds as a function of temperature. The vertical bars in A represent the standard error of the mean of three replications. In $\mathbf{B}$, the regression equations are $\mathrm{y}=-0.300+0.049 \mathrm{x}\left(r^{2}=0.77\right.$, matric-primed, solid line $) ; \mathrm{y}=-0.204+0.037 \mathrm{x}\left(r^{2}=0.78\right.$, osmotic-primed, dotted line $) ; \mathrm{y}=-0.181$ $+0.024 \mathrm{x}\left(r^{2}=0.94\right.$, nonprimed, dashed line $)$. In $\mathbf{C}$, the regression equations for 10 to $25 \mathrm{C}$ are $\mathrm{y}=-0.426+0.047 \mathrm{x}\left(r^{2}=0.98\right.$, matric-primed, solid line; $\mathrm{y}=-0.414+$ $0.039 \mathrm{x}\left(r^{2}=0.99\right.$, osmotic-primed, dotted line $) ; \mathrm{y}=-0.477+0.044 \mathrm{x}\left(r^{2}=0.95\right.$, nonprimed, dashed line $)$, and from 25 to $35 \mathrm{C} ; \mathrm{y}=2.576-0.068 \mathrm{x}\left(r^{2}=0.87\right.$, matricprimed, solid line); $\mathrm{y}=2.027-0.055 \mathrm{x}\left(r^{2}=0.88\right.$, osmotic-primed, dotted line); $\mathrm{y}$ $=1.876-0.051 \times\left(r^{2}=0.98\right.$, nonprimed, dashed line $) .{ }^{*}$ Germination at $42 \mathrm{C}$ was tested in a separate experiment. replications of 100 seeds each of 'Pinnacle' (Sakata Seeds America, Morgan Hill, Calif.) at 25C during days 1 and 7 of matric and osmotic priming. To inhibit microbial activity, a $0.01 \%(\mathrm{w} / \mathrm{v})$ streptomycin sulfate solution was used for matric and osmotic priming. The rate of $\mathrm{O}_{2}$ depletion from the gas phase of the sample chamber was determined when a constant $\mathrm{O}_{2}$ depletion rate was recorded on a strip chart recorder for at least $15 \mathrm{~min}$.

Electrolyte leakage. Electrical conductivity of seed leachate was measured 2.7, 5.3, 8.7, 11, 19, 26.5, 46, 52.5, or $73 \mathrm{~h}$ after the start of imbibition using a conductivity meter (model CDM 83; Radiometer, Copenhagen, Denmark) calibrated with $0.05 \% \mathrm{NaCl}$ at $28 \mathrm{C}$. Before testing, seeds were rinsed in distilled-deionized water for $2.5 \mathrm{~min}$ and blotted dry. Four replications of 5 seeds each were placed on 1-cm wedges of filter paper (Whatman no. 1) inside $5.0-\mathrm{cm}$-diameter petri dishes containing $2 \mathrm{ml}$ of distilled-deionized water. Dishes were tilted at $8^{\circ}$ inside self-sealing plastic bags and incubated in the dark at 20,35, and 40C. A few minutes before each measurement, dishes were equilibrated at $28 \mathrm{C}$ and gently swirled by hand several times to ensure uniform mixing of the solution. To estimate the maximum leakage, seeds were boiled in five times their volume of distilled-deionized water for $5 \mathrm{~min}$. Boiled seeds were rinsed in distilled-deionized water for $2.5 \mathrm{~min}$, surface dried, and imbibed as described above before testing.

\section{Results}

Priming. Several ratios of seed, carrier, and water were tested, and the ratio of $1.0 \mathrm{~g}$ seed: $0.8 \mathrm{~g}$ Micro-Cel E: $1.8 \mathrm{ml}$ water produced the highest rate of germination at most temperatures (data not shown). At this ratio, the moisture content of the Micro-Cel E was $62 \%$ (dry weight basis), the seed moisture content was $41 \% \pm$ $1.5 \%$, and the equilibrium $\Psi$ for the seed and Micro-Cel $E$ was $-1.2 \pm 0.2 \mathrm{MPa}$. A solution of $31 \mathrm{~g} \mathrm{PEG} / 100 \mathrm{ml}$ water produced the highest GR of any osmotic priming treatment tested (data not shown). The $\Psi$ of the PEG solution was initially $-1.1 \mathrm{MPa}$ but fell rapidly to an equilibrium $\Psi$ of $-1.3 \pm 0.2 \mathrm{MPa}$ due to the concentrating effects of imbibition. The equilibrium moisture content of seeds primed in PEG was $39.0 \% \pm 1.5 \%$. Matric or osmotic priming at higher $\Psi$ resulted in germination during priming, so the optimum enhancement occurred just below the $\Psi$ threshold for germination.

Table 2. Maximum $\left(\mathrm{T}_{\mathrm{m}}\right)$ and minimum $\left(\mathrm{T}_{\mathrm{b}}\right)$ temperatures for germination and root growth and thermal time constant $\left(\theta_{\mathrm{T}}\right)$ values for germination at $<30 \mathrm{C}$ for matric-primed, osmotic-primed, and nonprimed broccoli seeds.

\begin{tabular}{lccc}
\hline \hline Treatment & $\mathrm{T}_{\mathrm{b}}\left({ }^{\circ} \mathrm{C}\right)$ & $\mathrm{T}_{\mathrm{m}}\left({ }^{\circ} \mathrm{C}\right)$ & $\theta_{\mathrm{T}}\left({ }^{\circ} \mathrm{h}\right)$ \\
\hline \multirow{4}{*}{ Mermination } & & \\
Osmotic-primed & $6.1^{\mathrm{z}}$ & 37.6 & $204 \mathrm{a}$ \\
Nonprimed & 5.9 & 37.5 & $270 \mathrm{a}$ \\
& 7.8 & 36.1 & $417 \mathrm{~b}$ \\
& $\mathrm{NS}$ & $\mathrm{NS}$ & $* *$ \\
Matric-primed & Root growth & & \\
Osmotic-primed & 9.0 & 36.8 & 21.1 \\
Nonprimed & 12.0 & 36.3 & 25.7 \\
& 10.9 & 36.3 & 22.5 \\
& $\mathrm{NS}$ & $\mathrm{NS}$ & $\mathrm{NS}$
\end{tabular}

${ }^{\mathrm{z}}$ Means were calculated graphically from data in Fig. $1 \mathrm{~B}$ and $\mathrm{C}$ from three replications of 20 seeds each for seed germination and two replications of 10 seeds each for root growth. Means are significantly different by $\operatorname{LSD}_{0.05}$ when separated by different letters within columns.

Ns, ${ }^{* *}$ Nonsignificant or significant at $P=0.01$. 
Table 3. Oxygen uptake during priming, germination rate, and final germination percentage of matric- and osmotic-primed broccoli seeds.

\begin{tabular}{|c|c|c|c|c|}
\hline \multirow[b]{2}{*}{ Treatment } & \multicolumn{2}{|r|}{ Priming } & \multicolumn{2}{|c|}{ Germination } \\
\hline & Duration (days) & $\mathrm{O}_{2}$ uptake $(\mu \mathrm{mol} \mathrm{O} / \mathrm{h}$ per 100 seeds $)$ & Rate $\left(h^{-1}\right)$ & Percentage \\
\hline Matric-primed & 1 & $2.29 \mathrm{a}^{\mathrm{z}}$ & $0.05 \mathrm{a}$ & $89 \mathrm{a}$ \\
\hline Osmotic-primed & & $1.96 \mathrm{~b}$ & $0.04 \mathrm{a}$ & $89 \mathrm{a}$ \\
\hline Matric-primed & 7 & $1.92 \mathrm{~b}$ & $0.11 \mathrm{~b}$ & $97 \mathrm{~b}$ \\
\hline Osmotic-primed & & $1.65 \mathrm{c}$ & $0.06 \mathrm{a}$ & $84 \mathrm{a}$ \\
\hline Treatment & & $* *$ & $* *$ & $* *$ \\
\hline Duration & & $* *$ & $* *$ & NS \\
\hline Treatment $\times$ duration & & NS & NS & $*$ \\
\hline
\end{tabular}

${ }^{\mathrm{z}}$ Means for oxygen uptake and germination represent three replications of 100 and 20 seeds each, respectively, and are significantly different by $\mathrm{LSD}_{0.05}$ when numbers in columns are separated by different letters.

Ns,*,** Nonsignificant or significant at $P=0.05$ and 0.01 , respectively. Percentage data were arcsin-transformed before statistical analysis, and nontransformed values are shown.

Micro-Cel E contained more $\mathrm{Ca}, \mathrm{K}, \mathrm{Mg}$, and $\mathrm{Mn}$ than $\mathrm{PEG}$, although PEG was higher in P (Table 1). Primed seeds contained less $\mathrm{K}$ than nonprimed seeds (Table 1). Matric-primed seeds contained a higher percentage of Ca than either osmotic-primed or nonprimed seeds, while matric-primed and nonprimed seeds contained more $\mathrm{P}$ and $\mathrm{Fe}$ than osmotic-primed seeds (Table 1). The percentages of other elements did not differ among treatments.

Laboratory germination. Final germination percentages were similar for all treatments from 20 to 35C (Fig. 1A). Matric-primed seeds germinated at higher percentages than other treatments at $10 \mathrm{C}$, but at $5 \mathrm{C}$ there were no differences among treatments (Fig. 1A). At temperatures $>35 \mathrm{C}$, the germination percentages for primed and nonprimed seeds declined sharply. Germination of nonprimed seeds did not occur at $>36 \mathrm{C}$, while a small percentage of matric- and osmotic-primed seeds germinated at 40C (Fig. 1A).

The GR of nonprimed seeds increased linearly from 10 to a maximum at $30 \mathrm{C}$ and then declined sharply at higher temperatures (Fig. 1B). Priming increased GRs more near the optimum temperature for germination than at the extremes, so no change in $\mathrm{T}_{\mathrm{b}}$ was detected due to priming (Fig. 1B, Table 2). At most temperatures, the GR of matric-primed seeds was greater than that of osmoticprimed seeds (Fig. 1B).

The thermal time model in Eq. [2] was not accurate above 30C, as higher temperatures decreased germination rates resulting in negative estimates of $\theta_{\mathrm{T}}$ for all treatments. Therefore, $\theta_{\mathrm{T}}$ was only determined over the temperature range from 10 to $30 \mathrm{C}$. Priming lowered $\theta_{\mathrm{T}}$ by about $44 \%$ compared to nonprimed seeds, but there was no difference in the $\theta_{\mathrm{T}}$ values of matric- and osmotic- primed seeds (Table 2).

An accurate graphic determination of $\mathrm{T}_{\mathrm{m}}$ was not possible because of the abrupt decline in germination percentages $>30 \mathrm{C}$ (Fig. 1B). When $\mathrm{T}_{\mathrm{m}}$ was estimated using the temperature that reduced the germination percentage to $50 \%$, no differences were detected among treatments (Table 2).

Root growth. Root growth rates increased linearly from 10 to $25 \mathrm{C}$ (Fig. 1C). At temperatures $>25 \mathrm{C}$, root growth rates declined rapidly, and at $35 \mathrm{C}$ growth was almost totally inhibited (Fig. 1C). The root growth rates of matric-primed seeds were significantly higher than either osmotic- or nonprimed seedlings at most temperatures (Fig. 1C). The $T_{b}$ and $T_{m}$ for root growth were not changed by priming (Fig. 1C, Table 2 ).

Oxygen uptake during priming. After 1 day, PEG-primed seeds had a lower $\mathrm{O}_{2}$ uptake rate compared to matric-primed seeds, although the germination percentage and rate did not differ (Table 3). After 7 days, $\mathrm{O}_{2}$ uptake rate was lower for both treatments compared to the first day, and seeds primed in PEG had a lower $\mathrm{O}_{2}$ uptake rate (Table 3). Seeds matrically primed for 7 days also germinated at a greater rate than osmotically primed seeds (Table 3 ).

Electrolyte leakage. At 20C, the conductivity of leachate from boiled seeds increased rapidly during the first $10 \mathrm{~h}$ of imbibition

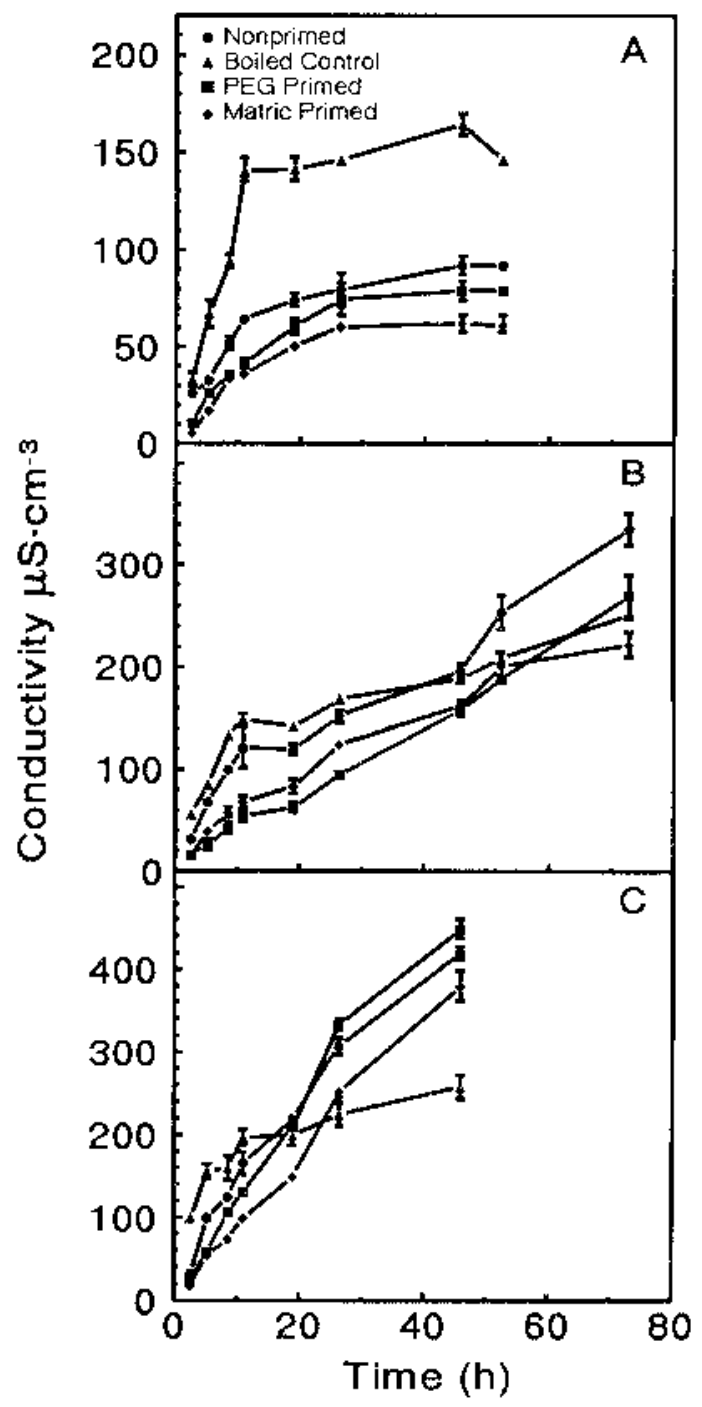

Fig. 2. Electrical conductivity of leachate from four replications of five boiled, matric-primed, osmotic-primed, and nonprimed broccoli seeds each measured after imbibition at 20C (A), 35C (B), or 40C (C). Error bars represent \pm sE when larger than the symbols. 
and then plateaued at $150 \mu \mathrm{S} \cdot \mathrm{cm}^{-3}$ (Fig. 2A). Electrolyte leakage from nonprimed seeds increased sharply during the first $10 \mathrm{~h}$ and then slowly to a maximum of $90 \mu \mathrm{S} \cdot \mathrm{cm}^{-3}$ (Fig. 2A). The conductivity of seeds primed in PEG increased more slowly than nonprimed seeds and peaked at $75 \mu \mathrm{S} \cdot \mathrm{cm}^{-3}$ (Fig. 2A). Matric-primed seeds showed the lowest conductivity during imbibition, with maximum values of $60 \mu \mathrm{S} \cdot \mathrm{cm}^{-3}$ (Fig. $2 \mathrm{~A}$ ).

At $35 \mathrm{C}$, the conductivity of boiled seeds was similar to 20C, increasing rapidly during the first $10 \mathrm{~h}$ and then at a slower rate to a maximum of $240 \mu \mathrm{S} \cdot \mathrm{cm}^{-3}$ at $73 \mathrm{~h}$ (Fig. 2B). The conductivity of nonprimed seeds was lower than boiled seeds during the first $40 \mathrm{~h}$ of imbibition and then increased sharply, exceeding the values for boiled seeds between 40 and $72 \mathrm{~h}$ (Fig. 2B). The conductivity of PEG-primed seeds was lower than nonprimed seeds and increased linearly to a maximum of $270 \mu \mathrm{S} \cdot \mathrm{cm}^{-3}$ at $72 \mathrm{~h}$ (Fig. 2B). The conductivity of PEG- and matric-primed seeds was similar during the first $55 \mathrm{~h}$ of imbibition. Longer imbibition times steadily increased the conductivity of PEG-primed seeds, while matricprimed seeds plateaued at $220 \mu \mathrm{S} \cdot \mathrm{cm}^{-3}$ (Fig. 2B).

At 40C, the electrolyte leakage from all treatments was greater than at $35 \mathrm{C}$. The conductivity of boiled seeds at $40 \mathrm{C}$ increased in a pattern similar to 20 and $35 \mathrm{C}$, but maximum values were less than for primed or nonprimed seeds (Fig. 2C). Electrolyte leakage from primed and nonprimed seeds increased linearly from the start of imbibition to $46 \mathrm{~h}$ (Fig. 2C). The conductivity of nonprimed seeds exceeded PEG-primed seeds during the first $10 \mathrm{~h}$ of imbibition, while PEG-primed seeds had the higher values during the final 20 h (Fig. 2C). After the first $5 \mathrm{~h}$ of imbibition, the conductivity of matric-primed seeds was lower than either nonprimed or PEGprimed seeds (Fig. 2C).

Emergence. The MTE for all primed seeds was lower than that of nonprimed seeds in a greenhouse (Table 4). Matric-primed seeds emerged earlier and had a greater final emergence percentage than nonprimed or osmotic-primed seeds, (Table 4). Sixteen DAS, matric-primed seedlings had greater shoot fresh and dry weights compared to osmotic-primed or nonprimed seeds due to the earlier emergence of matric-primed seeds (data not shown). There were no differences in root and shoot dry and fresh weights at 30 and 40 DAS (data not presented).

In 1992 and 1993, the mean daily field soil temperature during emergence was $24.4 \pm 1.6 \mathrm{C}$ and $27.6 \pm 1.3 \mathrm{C}$, respectively. There was no difference in the percent emergence among treatments in 1992 (Table 5). In 1993, the percentage emergence of matricprimed seeds was superior to osmotic and nonprimed seeds (Table 5). Both priming treatments reduced the MTE compared to nonprimed seeds. In both years, matric-primed seeds had a lower MTE than osmotic-primed seeds (Table 5).

\section{Discussion}

Effects of temperature on broccoli seed germination were similar to those in an earlier study, except that nonprimed seeds germinated to a higher percentage at $10 \mathrm{C}$ and were slightly more sensitive to high temperature (Elson et al., 1992). Seed germination at low temperature can be predicted using a thermal time model (Bradford, 1990; Garcia-Huidobro et al., 1982). Broccoli seed germination fits the thermal time model in Eq. [2] well for the temperature range of 5 to $30 \mathrm{C}$. The thermal time model showed that priming lowered $\theta_{\mathrm{T}}$ but had little effect on $\mathrm{T}_{\mathrm{b}}$, so primed broccoli seeds germinated faster because of their lower thermal time requirement (Fig. 1, Table 2). In other words, priming advanced germination more rapidly per unit thermal time than nonprimed seeds but did not reduce the minimum temperature for germination. Priming also lowered $\theta_{\mathrm{T}}$ and had no effect on $\mathrm{T}_{\mathrm{b}}$ of tomato (Lycopersicon esculentum Mill.) and onion (Allium cepa L.) seeds (Dahal and Bradford, 1990; Ellis and Butcher, 1988). In the absence of dormancy, $\mathrm{T}_{\mathrm{b}}$ is genotypically controlled and shows little variation within a species (Dahal and Bradford, 1990; Ellis and Butcher, 1988). Thus, priming lowers $T_{b}$ in seeds, such as muskmelon (Cucumis melo L.), by substituting for the afterripening requirement needed to overcome dormancy and increase the temperature range for germination (Welbaum and Bradford, 1991). Since broccoli seeds display little primary dormancy, $\mathrm{T}_{\mathrm{b}}$ was not altered by priming and should not vary significantly among cultivars (Jett and Welbaum, 1995).

At temperatures $>30 \mathrm{C}$, the thermal time model failed because GRs declined, resulting in negative $\theta_{\mathrm{T}}$ estimates (Fig. 1B). The $\mathrm{T}_{\mathrm{m}}$ could not be accurately estimated graphically due to the discontinuity in germination at high temperature (Fig. 1B). When $\mathrm{T}_{\mathrm{m}}$ was estimated by comparing the temperatures that inhibited the germination percentage by $50 \%$, there was no difference among seed treatments (Table 2). However, the maximum germination temperature for some seeds in the population was higher for primed than nonprimed seeds (Fig. 1A). Therefore, priming increased the $\mathrm{T}_{\mathrm{m}}$ for some seeds in the population, although mean maximum temperatures were similar among treatments (Bradford, 1990). Elson et al. (1992) reported that exposing broccoli seeds to temperatures $>35 \mathrm{C}$ for as little as $12 \mathrm{~h}$ reduced germination percentages even when alternated with lower temperatures. The amount of electrolyte leakage increased with increasing temperature, demonstrating that a loss of semipermeability in the plasma membrane may have reduced germination at high temperature (Fig. 2). Electrolyte leakage and germination percentage were negatively correlated in Brassica spp. seeds (Thornton et al., 1990). The plasma membrane plays an important role in the response of cells to temperature, and changes in fluidity and permeability occur at extreme temperatures (Raison, 1986).

The fastest root growth rates were obtained at $25 \mathrm{C}, 5 \mathrm{C}$ lower than the fastest GRs, indicating that root growth was favored by lower temperatures than germination (Fig. $1 \mathrm{~B}$ and $\mathrm{C}$ ). The $\mathrm{T}_{\mathrm{b}}$ for root growth was higher than for germination, and root growth rates in general were very slow at $<15 \mathrm{C}$ and $>30 \mathrm{C}$. Matric priming increased root growth rates at optimum temperatures but had little effect near $\mathrm{T}_{\mathrm{b}}$ and $\mathrm{T}_{\mathrm{m}}$ in a pattern similar to that described for GRs (Fig. 1C). Unlike germination, $\theta_{\mathrm{T}}$ for root growth was not changed by matric priming (Table 2). Elson et al. (1992) also showed that root growth was more sensitive to high and low temperatures than radicle emergence. Therefore, poor broccoli field emergence at high and low temperature may not be due to poor germination (i.e., radicle emergence) but rather an inhibition of root growth following radicle emergence (Fig. $1 \mathrm{~B}$ and $\mathrm{C}$ ). Examination of broccoli seed beds that produced poor stands under hot conditions revealed

Table 4. Seedling emergence of primed and nonprimed seeds in a greenhouse.

\begin{tabular}{lcc}
\hline \hline Treatment & MTE & Emergence \\
$(\%)$ & $(\mathrm{h})$
\end{tabular}

${ }^{\mathrm{z}}$ Means represent three replications of 10 seeds each and are significantly different by $\mathrm{LSD}_{0.05}$ when separated by different letters.

** Significant at $P=0.01$. Percentage data were arcsin-transformed before statistical analysis, and nontransformed values are shown. 
Table 5. Field emergence of primed and nonprimed broccoli seedlings in crusted soils.

\begin{tabular}{lccc}
\hline \hline & & MTE & \multicolumn{2}{c}{ Emergence } \\
Year & Treatment & $(\mathrm{h})$ & 74.3 \\
\hline 1992 & Matric-primed & $95.0 \mathrm{a}^{\mathrm{z}}$ & 66.3 \\
& Osmotic-primed & $117.8 \mathrm{~b}$ & 64.3 \\
& Nonprimed & $136.0 \mathrm{c}$ & $\mathrm{NS}$ \\
1993 & & $* * *$ & $75.6 \mathrm{a}$ \\
& Matric-primed & $85.3 \mathrm{a}$ & $61.3 \mathrm{~b}$ \\
& Osmotic-primed & $126.0 \mathrm{~b}$ & $54.4 \mathrm{~b}$ \\
Year & Nonprimed & $159.7 \mathrm{c}$ & $*$ \\
Year $\times$ treatment & & $* * *$ & $*$ \\
& & $*$ & $\mathrm{NS}$
\end{tabular}

${ }^{\mathrm{z}}$ Means represent three replications of 100 seeds each and are significantly different by $\mathrm{LSD}_{0.05}$ when separated by different letters. Ns,*,*** Nonsignificant or significant at $P=0.05$ and 0.001 , respectively. Percentage data were arcsin-transformed before statistical analysis, and nontransformed values are shown.

a high percentage of seeds that had germinated but failed to emerge because of slow root growth (data not shown).

The consistently higher root growth rates of matrically primed seeds was not anticipated, since previous studies have shown no persistent effect of priming on root growth rates in other species (Argerich and Bradford 1989; Green, 1980; Odell and Cantliffe, 1986). Haigh (1988) reported that primed tomato seedling roots had higher relative growth rates during the $12 \mathrm{~h}$ after radicle emergence, but no differences were detected $48 \mathrm{~h}$ after germination. However, only osmotic priming treatments were evaluated in previous studies, suggesting that matric priming may have increased root growth rates in this study.

Matric-primed seeds germinated faster than osmotic-primed seeds at most temperatures in the laboratory, greenhouse, and field. Since the equilibrium seed moisture content and $\Psi$ were similar for matric and osmotic priming treatments, the differential germination performance was not due to differences in hydration level during priming. In a previous study, there was no difference in the mean time and percent field emergence of broccoli seeds primed matrically in vermiculite or osmotically in PEG, suggesting that the superior performance of matric-primed seeds in the current study was due to effects of Micro-Cel E (Jett et al., 1995). Matric priming with Micro-Cel E enhances germination in some seeds to a greater degree than with other matric priming materials or osmotic priming treatments (Khan et al., 1992). Since seeds from both priming treatments were dried under the same conditions, differences were not caused by sensitivity to rapid drying. The superiority of Micro-Cel $\mathrm{E}$ as a priming agent may be due to its high water-holding capacity and high porosity that increases $\mathrm{O}_{2}$ availability (Khan et al., 1992). The solubility of $\mathrm{O}_{2}$ in PEG solutions is lower than water, and $\mathrm{O}_{2}$ may be limiting during osmotic priming treatments (Mexal et al., 1975). The $\mathrm{O}_{2}$ uptake rate was greater during matric priming than when seeds were primed in PEG (Table 3).

Electrolyte leakage from primed seeds, and particularly matricprimed seeds, was consistently less than nonprimed seeds at all temperatures (Fig. 2). Nonprimed seeds were washed briefly before conductivity testing to compensate for the leaching of solutes that occurred during priming and postpriming washing. However, the brief washing before conductivity testing may not have equalized solute losses among treatments.

PEG and Micro-Cel E contain significant plant-available quantities of several mineral nutrients (Table 1). The Ca content of matric-primed seeds increased, but the concentrations of other ions remained the same or, in the case of $\mathrm{K}$, declined (Table 1). This indicates that intracellular Ca increased during priming because, if Micro-Cel E was contaminating the seed surface during tissue analysis, then other nutrients present in the carrier would have increased as well. High Ca content is important for quality cucumber seeds (Frost and Kretchman, 1989). Calcium is essential for cell division, membrane function, the activation of protein kinases, and calmodulin-mediated processes (Roberts and Harmon, 1992). In addition to the increased $\mathrm{O}_{2}$ availability during priming and decreased electrolyte leakage during imbibition, increased seed $\mathrm{Ca}$ content is a third factor identified in this study that may explain why broccoli seeds matrically primed in Micro-Cel E outperform seeds osmotically primed in PEG.

\section{Literature Cited}

Argerich, C.A. and K.J. Bradford. 1989. The effects of priming and ageing on seed vigour in tomato. J. Expt. Bot. 40:599-607.

Bradford, K.J. 1986. Manipulation of seed water relations via osmotic priming to improve germination under stress conditions. HortScience 21:1105-1112.

Bradford, K.J. 1990. A water relations analysis of seed germination rates. Plant Physiol. 94:840-849.

Dahal, P. and K.J. Bradford. 1990. Effects of priming and endosperm integrity on seed germination rates of tomato genotypes. II. Germination at reduced water potential. J. Expt. Bot. 41:1431-1439.

Donohue, S.J. and S.E. Heckendorn. 1994. Laboratory procedures. Va. Tech. Soil Testing and Plant Anal. Lab., Publ. 452-881, Va. Coop. Ext. Serv., Blacksburg.

Ellis, R.H. and P.D. Butcher. 1988. The effects of priming and 'natural' differences in quality amongst onion seed lots on the response of the rate of germination to temperature and the identification of the characteristics under genotypic control. J. Expt. Bot. 39:935-950.

Elson, M.K., R.D. Morse, D.D. Wolf, and D.H. Vaughn. 1992. High temperature inhibition of seed germination and seedling emergence of broccoli. HortTechnology 2:417-419.

Frost, D.J. and D.W. Kretchman. 1989. Calcium deficiency reduces cucumber fruit and seed quality. J. Amer. Soc. Hort. Sci. 114:552-556.

Garcia-Huidobro, J., J.L. Monteith, and G.R. Squire. 1982. Time, temperature, and germination of pearl millet (Pennisetum typhoides $\mathrm{S} \& \mathrm{H}$.). I. Constant temperature. J. Expt. Bot. 33:288-296.

Green, J.C.S. 1980. Plant density and crop establishment studies with tomato. Acta Hort. 100:129-135.

Gummerson, R.J. 1986. Effect of constant temperatures and osmotic potentials on the germination of sugar beet. J. Expt. Bot. 37:729-741.

Haigh, A.M. 1988. Why do tomato seeds prime? PhD diss. Macquarie Univ., Sydney, Australia.

Heather, D.W. and J.B. Sieczka. 1991. Effect of seed size and cultivar on emergence and stand establishment of broccoli in crusted soil. J. Amer. Soc. Hort. Sci. 116:946-949. 
Heydecker, W. and P. Coolbear. 1977. Seed treatments for improved performance. Survey and attempted prognosis. Seed Sci. Technol. 5:353-425.

International Seed Testing Association. 1985. International rules for seed testing. Seed Sci. Technol. 13:299-520.

Jett, L.W. and G.E. Welbaum. 1995. Changes in broccoli (Brassica oleracea $\mathrm{L}$.) seed weight, viability, and vigour during development and following drying and priming. Seed Sci. Technol. (In press.)

Jett, L.W., G.E. Welbaum, C.R. O’Dell, and R.D. Morse. 1995. Does primed seed improve stand establishment and yield of broccoli? HortTechnology 5:314-317.

Khan, A.A., N.H. Peck, and C. Samimy. 1980-81. Seed osmoconditioning: physiological and biochemical changes. Israel J. Bot. 29:133-144.

Khan, A.A. 1992. Preplant physiological seed conditioning. Hort. Rev. 51:53-76.

Mexal, J., J.T. Fisher, J. Osteryoung, and C.P. Reid. 1975. Oxygen availability in polyethylene glycol solutions and its implications in plant water relations. Plant Physiol. 55:20-24.

Michel, B.E. 1983. Evaluation of the water potentials of solutions of polyethylene glycol 8000 in the absence and presence of other solutes. Plant Physiol. 72:66-70.

McCormac, A.C. and P.D. Keefe. 1990. A modified slant board test for vigour testing brassicas. Plant Var. Seeds 3:81-87.

O’Dell, C.R. 1990. Improving broccoli stands. Amer. Veg. Grower 38:25-27.

Odell, G.B. and D.J. Cantliffe. 1986. Seed priming procedures and the effect of subsequent storage on the germination of fresh market tomato seeds. Proc. Fla. State Hort. Soc. 99:303-306.

Raison, J.K. 1986. Alterations in the physical properties and thermal response of membrane lipids: Correlations with acclimation to chilling and high temperature, p. 383-401. In: J.B. St. John, E. Berlin, and P.C. Jackson (eds.). Frontiers of membrane research in agriculture. Rowman and Allanheld, Totowa, N.J.

Rao, S.C., S.W. Akers, and R.M. Ahring. 1987. Priming Brassica seed to improve emergence under different temperatures and soil moisture conditions. Crop Sci. 27:1050-1053.

Roberts, D.M. and A.C. Harmon. 1992. Calcium-modulated proteins: targets of intracellular calcium signals in higher plants. Annu. Rev. Plant Physiol. 43:375-414.

Scott, S.J. and R.A. Jones. 1985. Cold tolerance in tomato. I. Seed germination and early seedling growth of Lycopersicon esculentum. Physiol. Plant. 65:487-492.

Sterrett, S.B., J.W. Mapp, and C.W. Coale. 1990. Feasibility of broccoli as a new enterprise-A systems approach. HortScience 25:638-641.

Thornton, J.M., A.A. Powell, and S. Matthews. 1990. Investigation of the relationship between seed leachate and the germination of Brassica seed. Ann. Applied Biol. 117:129-135.

Welbaum, G.E. and K.J. Bradford. 1991. Water relations of seed development and germination in muskmelon (Cucumis melo L.). VI. Influence of priming on germination responses to temperature and water potential during seed development. J. Expt. Bot. 42:393-399.

Zheng, G., R.W. Wilen, A.E. Slinkard, and L.V. Gusta. 1994. Enhancement of canola seed germination and seedling emergence at low temperature by priming. Crop Sci. 34:1589-1593. 